\title{
TAKING MEASURE OF THE CHARTER'S EQUALITY GUARANTEE: A COMMENT ON THE COURT OF APPEAL'S RULING IN MORROW V. ZHANG
}

\author{
BARBARA BILLINGSLEY*
}

\section{INTRODUCTION}

On 12 June 2009, the Alberta Court of Appeal released its decision in Morrow. ${ }^{1}$ The central issue in the case was whether Alberta's minor injury cap ${ }^{2}$ unjustifiably violates the right to equality guaranteed by s. 15(1) of the Canadian Charter of Rights and Freedoms. ${ }^{3}$ Overturning the trial judgment of Neil Wittman A.C.J., ${ }^{4}$ the Court of Appeal concluded that the minor injury cap does not violate the Charter's equality guarantee. The appeal Court held that, when looked at in the context of the province's overall regulatory scheme of automobile accident insurance, the minor injury cap does not perpetuate a negative stereotype of individuals who suffer minor soft tissue injuries in motor vehicle accidents.

Subject to a further appeal to the Supreme Court of Canada, ${ }^{5}$ the Court of Appeal's unanimous ruling restores the minor injury cap as an operative component of Alberta's system of motor vehicle accident injury recovery. In doing so, however, the appeal Court's judgment raises crucial questions about the proper interpretation and application of the Charter's equality guarantee. My purpose in writing this comment is not to resolve these questions. Instead, my more modest ambition is to identify these issues, to explain how they arise from the Court's judgment in Morrow, and to demonstrate, with reference to the outcome in Morrow, why the resolution of these issues is critical to a clear and meaningful application of the Charter's equality guarantee in future cases.

I begin this discussion in Part II by briefly reviewing the circumstances that put the equality question before the Court of Appeal and by summarizing the findings of the trial judge and the Court of Appeal on the s. 15(1) challenge. ${ }^{6}$ In Part III, I consider three critical

Associate Professor, Faculty of Law, University of Alberta. Thanks to Peter Lown, Q.C. of the Alberta Law Reform Institute, Professor Eric Adams of the University of Alberta Faculty of Law, and Johnson Billingsley, respectively, for their helpful comments on previous drafts of this comment. Morrow v. Zhang, 2009 ABCA 215, 454 A.R. 221 [Morrow]. The constitutionality of the minor injury cap was raised as an issue soon after the cap was put into place in 2004, however it took some time to bring this question before the courts. The trial was heard in the spring of 2007; the trial judgment was issued on 8 February 2008; and the appeal was argued on 12 September 2008.

2 As instituted by Alberta's Minor Injury Regulation, Alta. Reg. 123/2004, s. 6 [MIR]. For an overview of the content and operation of this and other associated regulations, see Part II of this comment.

3 Part I of the Constitution Act, 1982, being Schedule B to the Canada Act 1982 (U.K.), 1982, c. 11 [Charter]. Section 15(1) provides as follows:

Every individual is equal before and under the law and has the right to the equal protection and equal benefit of the law without discrimination and, in particular, without discrimination based on race, national or ethnic origin, colour, religion, sex, age or mental or physical disability.

4 Morrow v. Zhang, 2008 ABQB 98, 421 A.R. 1 [Morrow, Q.B.].

5 On 22 July 2009, news sources reported that the claimants in Morrow would be applying for leave to appeal the Court of Appeal ruling to the Supreme Court of Canada: see e.g. “Alberta Auto Cap Heads to Supreme Court of Canada” Canadian Underwriter (22 July 2009), online: Canadian Underwriter $<$ http://www.canadianunderwriter.ca/issues/ISArticle.asp?aid=1000335403>.

$6 \quad$ In this comment, I do not discuss the judicial findings on the s. 7 or s. 1 Charter arguments. These issues are not central to the divergent findings of the trial and appeal courts. In short, the courts agreed that s. 7 of the Charter is not violated by the minor injury cap. The trial judge found that the s. 15(1) violation was not justified under s. 1 of the Charter, but the Court of Appeal made only brief obiter comments regarding s. 1 , given its finding that the minor injury cap does not violate s. 15(1). 
issues regarding the Charter's equality guarantee that I believe are raised by the Court of Appeal's judgment. Finally, in Part IV, I offer an alternative approach to that taken by the Court of Appeal in analyzing the constitutionality of the minor injury cap under s. 15(1) of the Charter, given the issues identified in Part III.

\section{BACKGROUND OF MORROW V. ZHANG}

\section{A. The Minor InJury CAP ${ }^{7}$}

On 4 December 2003, the Alberta legislature passed the Insurance Amendment Act, 2003, ${ }^{8}$ a statute designed to significantly reform Alberta's automobile insurance scheme. Under the authority of this statute, a series of regulations regarding automobile insurance and motor vehicle accident injury recovery took effect on 1 October 2004. The regulations particularly relevant to the s. 15(1) issue raised in Morrow are the Motor Injury Regulation, ${ }^{9}$ the Diagnostic and Treatment Protocols Regulation, ${ }^{10}$ and the Automobile Accident Insurance Benefits Regulation. ${ }^{11}$

The MIR provides that an individual who suffers a "minor injury" in a motor vehicle accident (a "minor injury claimant") is entitled to recover a maximum of $\$ 4,000$ for nonpecuniary damages from the tortfeasor who caused the accident. ${ }^{12}$ For the purposes of this damages cap, a minor injury is defined as a soft tissue injury (identified in the regulations as a sprain, strain, or low-grade whiplash injury) that does not result in long-term and substantial inability to perform essential daily tasks. ${ }^{13}$ The $D T P R$ is closely related to the $M I R$. It requires individuals who suffer a sprain, strain, or mild whiplash injury (that is, a minor injury) in a motor vehicle accident to pursue a series of specific diagnostic and treatment protocols. These protocols require a health care practitioner, upon identifying a claimant's injury as a sprain, strain, or whiplash, to prescribe a treatment regime drawn from a series of recommended treatments set out in the regulations. ${ }^{14}$ If the health care practitioner is uncertain as to the appropriate treatment for the claimant, or if the claimant's condition is not substantially resolving appropriately or as expected within 90 days, a referral may be made to a medical practitioner who is registered under the DTPR as an "injury management consultant." ${ }^{15}$ Amongst other qualifications, an "injury management consultant” must be versed in the biopsychosocial treatment model, ${ }^{16}$ a treatment philosophy that is not defined

This is a purposely brief review of the history and content of Alberta's minor injury cap. For more detailed discussion of the relevant legislative and regulatory provisions, see: Morrow, Q.B., supra note 4 at paras. 68-102; Morrow, supra note 1 at paras. 8-23; Barbara Billingsley, "Legislative Reform and Equal Access to the Justice System: An Examination of Alberta’s New Minor Injury Cap in the Context of Section 15 of the Canadian Charter of Rights and Freedoms” (2005) 42 Alta. L. Rev. 711; Peter B. Michalyshyn, Q.C., "The Diagnostic and Treatment Protocols Regulation and the Minor Injury Regulation: Review and Commentary” (2005) 42 Alta. L. Rev. 923. Bill 53, Insurance Amendment Act, 2003 (No. 2), 3d Sess., 25th Leg., Alberta, 2003 (assented to 4 December 2003), S.A. 2003, c. 40.

MIR, supra note 2.

Alta. Reg. 122/2004 [DTPR].

Alta. Reg. 352/72, as am. by the Automobile Accident Insurance Benefits Amendment Regulation, Alta. Reg. 121/2004 [AAIBR].

MIR, supra note 2, s. 6. This regulation has been amended to adjust the cap for inflation: see Alta. Reg. 260/2006, s. 3.

MIR, ibid., ss. 1(h), (j), (k), (l), (n).

DTPR, supra note 10 , ss. 6-21.

Ibid., ss. 24-25.

Ibid., s. 27(2). 
in the regulations but which has elsewhere been described as viewing chronic pain associated with whiplash as a "social disorder" rather than a purely physical condition. ${ }^{17}$ If an accident victim who suffers a sprain, strain, or whiplash injury fails to follow these protocols without reasonable excuse, the MIR deems that person to be subject to the minor injury cap even if the injury leads to serious impairment. In this circumstance, the burden is on the claimant to prove that the minor injury designation should not be applied because the serious impairment would have occurred even if the regulatory treatment protocols had been followed. ${ }^{18}$ The MIR also provides a claimant with an opportunity to challenge the minor injury classification by having his or her medical condition assessed by a certified examiner. ${ }^{19}$ The opinion of the certified examiner is prima facie evidence that the claimant's injury is, or is not, a minor injury. $^{20}$

The AAIBR facilitates the DTPR protocols by increasing benefits up to $\$ 50,000$ for medical treatment for all automobile accident injury victims insured under s. B of an owner's policy of automobile insurance. ${ }^{21}$ The $D T P R$ also makes some initial treatments payable by the insurer on a pre-authorized basis, without any financial expenditure by the injured person. $^{22}$

\section{B. The Claims in Morrow V. Zhang}

The case indexed as Morrow actually includes two separate lawsuits, both involving damage claims for soft tissue injuries suffered by the claimants in motor vehicle accidents. The first lawsuit was commenced by Peari Morrow to recover compensation for soft tissue injuries to her upper back and neck arising from a motor vehicle accident that took place on 21 October 2004. Morrow sued Ziao Fei Wei and Jian Yue Zhang, the owner and driver, respectively, of the vehicle that struck the Morrow vehicle. The second lawsuit was commenced by Brea Pedersen to recover compensation for soft tissue injuries to her neck, shoulders, back, and wrists arising from a motor vehicle accident that occurred on 22 March 2005. Pedersen sued Robert Van Thournout and Darin James Van Thournout, the owner and driver, respectively, of the vehicle that struck the Pedersen vehicle. In both lawsuits liability was admitted by the defendants so litigation proceeded on the question of damages.

Under the regulatory protocols, the injuries suffered by Morrow and Pedersen had been classified as minor injuries. This brought the MIR into play, meaning that each claimant was limited to a maximum non-pecuniary damages recovery of $\$ 4,000$. Morrow and Pedersen each challenged the constitutionality of the minor injury cap, arguing that the cap unjustifiably violated s. 15(1) of the Charter. ${ }^{23}$ At trial and on appeal, Her Majesty the Queen

See Michalyshyn, supra note 7 at 931-32.

MIR, supra note 2, s. 5(1).

Ibid., s. 8.

Ibid., s. 12.

AAIBR, supra note 11 , Sch. A.

DTPR, supra note 10 , ss. 32-38.

The claimants also each challenged the minor injury cap as an unjustified violation of the Charter, supra note 3, s. 7, which provides that: "Everyone has the right to life, liberty and security of the person and the right not to be deprived thereof except in accordance with the principles of fundamental justice.” As explained in supra note 6, I do not discuss the s. 7 argument in this comment. 
in Right of Alberta (the Crown) and the Insurance Bureau of Canada (IBC) intervened on the constitutional questions. ${ }^{24}$

\section{THE QUEEN's BENCH RULING}

On 8 February 2008, Wittmann A.C.J. issued his trial judgment on the Morrow and Pedersen claims. Prior to considering the constitutionality of the minor injury cap, Wittmann $\mathrm{J}$. assessed non-pecuniary damages at $\$ 20,000$ for Morrow and $\$ 15,000$ for Pedersen. This finding made the constitutional questions relevant by making it clear that, but for the minor injury cap, each claimant would have been entitled to recover more than $\$ 4,000$ in nonpecuniary damages.

As a preliminary step to the substantive consideration of the equality issue, Wittmann $\mathrm{J}$. dealt with the question of whether his analysis should focus on the minor injury cap alone or on the automobile insurance reform package as a whole, including particularly the MIR, the $D T P R$, and the AAIBR. The claimants challenged only the minor injury cap. The interveners, however, argued that the s. 15(1) evaluation of the minor injury cap must consider the automobile insurance reforms as a whole because these reforms were designed to operate as a comprehensive package in which the MIR, the DTPR, and the AAIBR in particular facilitate one another. ${ }^{25}$ Justice Wittmann rejected this argument, holding that the interveners were confusing the contextual considerations relevant to a s. 15(1) analysis with

The Crown had intervener status as of right pursuant to the Judicature Act, R.S.A. 2000, c. J-2, s. 24(4). IBC was granted intervener status by court order. The Dominion of Canada General Insurance Company sought leave to intervene at the appeal hearing, but this application was denied by the Court of Appeal: see Morrow v. Zhang, 2008 ABCA 192, 432 A.R. 219.

As summarized by Wittman J. in Morrow, Q.B., supra note 4, at paras. 153-59:

The Interveners submit that, although the Plaintiffs have narrowed their constitutional challenge to the MIR, the Insurance Reforms as a group are "inextricably connected parts of a comprehensive and balanced package". Accordingly, they argue that the Court should evaluate the constitutionality and any potential remedy on an analysis of the entire legislative scheme.... the Interveners argue that the MIR has funded a large portion of the Other Regulations. They also point out that the DTPR and the MIR are connected because the MIR promotes participation in the DTPR.

[T] he Interveners routinely rely on the benefits provided by the DTPR and the Automobile Accident Insurance Benefits Amendment Regulation to demonstrate that the cap does not violate s. 15(1) of the Charter.

Specifically, the Interveners point out that the DTPR establishes protocols for the diagnosis and treatment of sprains, strains and WADs grade I and II that are evidence-based and in accordance with best practices. They also note that the DTPR provides for pre-authorized payment for the treatment of Minor Injuries, dispensing with the need to seek approval from the insurance companies or to pay out-of-pocket up-front. Accordingly, no authorization is required for the first 90 days following an accident in relation to pre-approved treatments and services set out under the DTPR. If an injury has not resolved, or is not resolving as expected, after these resources are exhausted, a health care practitioner can refer the claimant to an Injury Management Consultant ("IMC"). The IMC can complete an individualized report on the claimant which could lead to further treatments and assessments, including a referral for a multi-disciplinary assessment. The Intervenors also note that the Automobile Accident Insurance Benefits Amendment Regulation has increased Section B benefits from $\$ 10,000$ to $\$ 50,000$. They submit that these advances are of great benefit to Minor Injury victims when compared with the state of care pre reform, at which time inconsistent and non-evidence based techniques were used to diagnose and treat sprains, strains and WADs.

The Intervenors called evidence to demonstrate that the rate of closure of claims by insurers in the weeks following an accident has been on the rise since the implementation of the Insurance Reforms. They also demonstrated that early diagnosis and treatment following an accident, which are facilitated by the DTPR, appear beneficial to injury victims....

They submit that this makes clear the beneficial results that the Insurance Reforms as a package are having in terms of improving the circumstances of Minor Injury victims. 
those relevant to a s. 1 analysis. Accordingly, the trial judge focused his equality analysis on the minor injury cap, considering the comprehensive scheme of automobile insurance reforms only "as part of the contextual analysis prescribed in Law v. Canada ... in relation to s. $15(1)$, and in $R$. v. Oakes ... regarding s. $1^{\text {”26 }}$

Moving to the substantive s. 15(1) analysis, Wittmann J. applied the then prevailing test (the Law test) set out by the Supreme Court of Canada in Law. ${ }^{27}$ The Law test consists of three inquiries:

1. Does the impugned law

(a) "[D]raw a formal distinction between the claimant and others in purpose and effect on the basis of personal characteristics?” or

(b) “[F]ail to take into account the claimant's already disadvantaged position within Canadian society resulting in substantively different treatment between the claimant and others on the basis of personal characteristics?”

2. "[W]as the claimant subject to differential treatment on the basis of one or more enumerated and analogous grounds?”

3. “[D]oes the differential treatment discriminate in a substantive sense, bringing into play the purpose of s. 15(1) in remedying such ills as prejudice, stereotyping, and historical disadvantage?” In other words, does the law in question have a purpose or effect that is discriminatory within the meaning of the equality guarantee? ${ }^{28}$

Justice Wittman held that all elements of this test are satisfied by the MIR.

With respect to the first prong of the Law test, Wittmann J. found that the MIR draws a distinction between minor injury claimants, like Morrow and Pedersen, and motor vehicle accident victims who suffer other types of injuries. Further, by setting a $\$ 4,000$ limit on the recovery of non-pecuniary damages for minor injury claimants, the MIR imposes a disadvantage on minor injury claimants that is not imposed on other motor vehicle accident claimants. Under the second part of the Law test, Wittmann J. held that the differential treatment imposed by the minor injury cap is based on physical disability, which is a listed ground of discrimination under s. 15(1). In making this finding, Wittmann J. rejected the IBC's argument that physical disability requires an "obvious physical impairment." 29 Finally, with regard to the third component of the Law test, Wittmann J. concluded that the MIR substantively discriminates against minor injury claimants by perpetuating the view that such people are not genuinely injured and are either malingering or are being fraudulent in order to gain a financial benefit. Justice Wittmann made this finding by applying the four

Ibid, at para. 160 .

Law v. Canada (Minister of Employment and Immigration), [1999] 1 S.C.R. 497 [Law].

Ibid. at para. 39.

Morrow, Q.B., supra note 4, at paras. 190-94. The Crown conceded that the differential treatment was based on a physical disability. 
contextual factors that are identified in Law (the Law factors) as being indicators of substantive discrimination.

The first Law factor asks whether the group or person singled out by the challenged legislation suffers from a pre-existing disadvantage, vulnerability, stereotyping, or prejudice. If so, this factor weighs in favour of a finding of substantive discrimination. Based on the evidence at trial, Wittmann J. concluded that minor injury claimants have been historically stereotyped as malingerers or fraudsters. He also found that the minor injury cap perpetuates this stereotype by suggesting that minor injury claimants are less worthy of being compensated by general damage awards than automobile accident victims who incur injuries that are "objectively verifiable." ${ }^{30}$ With regard to the suggestion that the MIR does not perpetuate a negative stereotype when it is considered in light of the treatment benefits made available to minor injury claimants under the $D T P R$ and the AAIBR, Wittmann J. stated:

In my view, the reasonable claimant would conclude that the MIR has the effect of perpetuating the stereotype that soft tissue injury victims are malingerers and fraudsters or that their pain is not real. This view is based on the knowledge that they are limited to compensation of $\$ 4,000$, whereas those that suffer from objectively verifiable injuries that may suffer less pain, would be entitled to pursue greater non-pecuniary damages. This conclusion is not overcome by an awareness of the benefits provided under the Automobile Accident Insurance Benefits Amendment Regulation, because few soft tissue injury victims require treatment costing in excess of $\$ 10,000 \ldots$. Additionally, these benefits are provided to all automobile accident injury victims. Although the DTPR provides for preauthorized treatments and other benefits to Minor Injury victims which have been referenced above, those benefits would, from the perspective of the reasonable claimant, be insufficient to neutralize the effect of the cap on their dignity. ${ }^{31}$

Accordingly, Wittman J. concluded that the first Law factor was met by the minor injury cap.

The second Law factor requires a court to assess the degree of correspondence between the ground upon which the differential treatment is based and the actual needs, characteristics, and circumstances of the claimant group. The closer the differential treatment matches with the actual requirements and circumstances of the claimant group, the less likely it is that the differential treatment is discriminatory. On this point, Wittmann J. concluded that, by restricting the value of non-pecuniary damages recoverable by minor injury claimants, the MIR fails to meet the essential need of these claimants for individualized, fair, and full compensation for their injuries. Justice Wittmann also rejected the suggestion that the individual needs of accident injury victims are met by the personal assessment and treatment of accident victims prescribed by the regulations. He found that

[a]lthough there appears to be a tight correspondence between the needs, capacities and circumstances of the claimant group and the DTPR and, to a lesser extent, the Automobile Accident Insurance Benefits Amendment Regulation, no such correspondence exists between that group and the MIR. 
In assessing whether the MIR meets the needs, capacities and circumstances of the claimant group, the reasonable person in the shoes of the claimant would be aware that, in effect, the Government has attempted to finance the resolution of what it perceived to be a crisis, on the backs of a discrete group of injury victims who are disabled as the result of a particular type of injury. The reasonable person standing in the place of the claimant would not, in my view, be persuaded that the benefits provided under the Other Regulations offset or otherwise address the fact that the claimant group is excluded from claiming non-pecuniary damages in excess of \$4,000, particularly given the knowledge that some Minor Injury sufferers go on to suffer long term, chronic pain. ${ }^{32}$

In short, Wittman J. found that, while the individualized assessment and treatment provided under the DTPR and the AAIBR might meet some needs of minor injury victims, they do not meet the need for individualized and full compensation for non-pecuniary loss. In other words, the personalized offerings of the DTPR and the AAIBR do not overcome the fact that, once the personalized assessments available under these regulations cast an individual into the class of minor injury claimants, the minor injury cap negatively treats all minor injury claimants as a class, and not as individuals, for the purposes of assessing general damages.

The third Law factor asks if the purpose or effect of the legislative distinction is to ameliorate the condition of a more disadvantaged group. A distinction that has such an ameliorative purpose or effect is less likely to be discriminatory. Justice Wittman held that the minor injury cap is "not aimed at improving the circumstances of other more disadvantaged groups.”33

The final Law factor focuses on the nature and scope of the interest affected by the legislative distinction. In Law, the Supreme Court explained this factor as follows:

\footnotetext{
"If all other things are equal, the more severe and localized the ... consequences on the affected group, the more likely that the distinction responsible for these consequences is discriminatory”.... [T] he discriminatory calibre of differential treatment cannot be fully appreciated without evaluating not only the economic but also the constitutional and societal significance attributed to the interest or interests adversely affected by the legislation in question. Moreover, it is relevant to consider whether the distinction restricts access to a fundamental social institution, or affects “a basic aspect of full membership in Canadian society” or “constitute[s] a complete non-recognition of a particular group." 34
}

Justice Wittmann held that the interest affected by the minor injury cap "is the ability of Minor Injury victims to recover damages in tort for their pain and suffering in an amount greater than $\$ 4,000 . ” 35$ With respect to the nature and significance of the interest affected, Wittmann J. concluded that the cap has a negative economic and societal impact on minor injury claimants. He reasoned that, even though the benefits provided by the DTPR and the $A A I B R$ "do recognize the pain of the claimant group by providing immediate and consistent

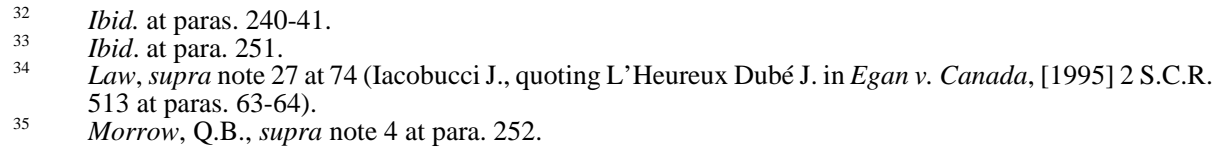


treatment," ${ }^{36}$ the minor injury cap is nonetheless discriminatory because "[t]he restricted availability of non-pecuniary damages results in a diminished recognition of the claimant group's pain and suffering relative to that of motor vehicle accident victims that have suffered other kinds of injuries." ${ }^{37}$ He also noted that the cap makes it more difficult for minor injury accident victims to obtain legal counsel on a contingency basis and that the ability to pursue recovery by legal action is an important economic and societal interest.

So, on the basis of his consideration of the Law factors, Wittmann J. concluded that the MIR is substantively discriminatory and therefore a violation of s. 15(1) of the Charter. He then went on to apply s. 1 of the Charter and concluded that the minor injury cap is not justifiable as a "reasonable limit" on the equality right. ${ }^{38}$ Accordingly, Wittmann J. struck down the MIR as an unjustifiable violation of s. 15(1) of the Charter and awarded each of the claimants the full value of their assessed general damages. ${ }^{39}$

\section{The Court of Appeal Ruling}

Justice Wittmann's findings on the s. 15(1) and s. 1 Charter issues were appealed by the defendants and both interveners. Morrow and Pedersen each cross-appealed on the s. 7 question. In the result, the Court of Appeal overturned Wittmann J.'s ruling on s. 15(1) but upheld his finding on s. 7. Having therefore found no Charter violation, the Court of Appeal did not make a s. 1 finding. ${ }^{40}$

Writing for a unanimous Court of Appeal, Rowbotham J.A. began her analysis of the equality issue by noting that while the Law test was the relevant standard for assessing a s. 15(1) violation at the time of the trial, the relevant test has since been recast by the Supreme Court of Canada in Kapp. ${ }^{41}$ Specifically, Rowbotham J. found that in Kapp, and subsequently confirmed in Ermineskin, ${ }^{42}$ the Supreme Court changed the equality analysis by holding that the concept of human dignity should not be used as the measure for finding discrimination. As described by Rowbotham J., "since Kapp, for a section 15 challenge to succeed, it is still necessary for a claimant to establish something in addition to disadvantage based on an enumerated or analogous ground. The additional something (discrimination) is no longer an impairment of human dignity, but rather the perpetuation of disadvantage or stereotyping." ${ }^{43}$

Ibid. at para. 256.

Ibid. at para. 255.

The Charter, supra note 3, s. 1 provides that: "The Canadian Charter of Rights and Freedoms guarantees the rights and freedoms set out in it subject only to such reasonable limits prescribed by law as can be demonstrably justified in a free and democratic society." Pursuant to this provision, legislation that violates a Charter right can still be constitutionally viable if it constitutes a "reasonable limit" on the right in question. See Morrow, Q.B., ibid. at paras. 275-347 for Wittmann J.'s s. 1 analysis.

Morrow was awarded \$21,000 in total damages: \$20,000 for non-pecuniary damages and \$1,000 for special damages. Pedersen was awarded \$15,000 for non-pecuniary damages: see Morrow, Q.B., ibid. at para. 356.

The Court of Appeal did, however, make some brief obiter comments relating to s. 1: see Morrow, supra note 1 at para. 148. In particular, the Court found that Wittman J. erred in his s. 1 analysis by focusing on the MIR instead of the whole automobile insurance regulatory scheme. The appeal Court also noted that s. 1 has virtually no effective role to play in a Charter analysis where a s. 15(1) breach has been made out. The latter point is discussed in detail in Part III.C of this comment.

R. v. Kapp, 2008 SCC 41, [2008] 2 S.C.R. 483 [Kapp].

Ermineskin Indian Band and Nation v. Canada, 2009 SCC 9, [2009] 1 S.C.R. 222 [Ermineskin]. Morrow, supra note 1 at para. 52. 
Nevertheless, Rowbotham J. rejected the suggestion that this change means that Wittmann J. erred in applying the Law factors as part of his s. 15(1) analysis:

\begin{abstract}
The appellant, IBC, suggests that the trial judge's many references to "human dignity" evidence an error of law in light of Kapp. I note that the Supreme Court in Kapp at para. 23 endorsed the four contextual factors from Law, but ascribed different purposes to them. The Supreme Court's decision in Ermineskin does not mention the Law contextual factors, and hence their impact on the section 15(1) analysis is unclear. Accordingly, this Court must assess the trial judge's application of the Law contextual factors. I acknowledge that in light of Kapp and Ermineskin and the academic commentary on these cases, the focus of the discrimination analysis should be directed to two concepts: (1) the perpetuation of prejudice and disadvantage to members of a group on the basis of personal characteristics identified in the enumerated and analogous grounds, and (2) stereotyping on the basis of these grounds that do not correspond to a claimant's or group's actual circumstances and characteristics. ${ }^{44}$
\end{abstract}

Accordingly, Rowbotham J. concluded that the Court of Appeal was required to assess the trial judge's application of the Law factors with the understanding that these factors should be focused on the question of whether the minor injury cap is substantively discriminatory, rather than on the question of whether the minor injury cap negatively impacts on the human dignity of minor injury claimants.

In reviewing Wittmann J.'s application of the Law test, Rowbotham J. found that the trial judge had correctly identified the relevant comparator groups for the equality analysis. She also conceded that the legislative distinction of minor injury claimants was drawn on the prohibited ground of physical disability. However, Rowbotham J. disagreed with the trial judge's finding that the minor injury cap was substantively discriminatory. Justice Rowbotham found that Wittmann J. erred by focusing his analysis too closely on the minor injury cap and failing to consider the overall effect of the automobile insurance reforms. While she found "no reversible error" 45 with respect to Wittmann J.'s conclusion on the third Law factor (that is, that the legislation was not aimed at ameliorating the condition of a more disadvantaged group), she concluded that he erred in his findings on the three other Law factors.

With regard to the first Law factor (whether the claimant group had suffered from a historical stereotype that was perpetuated by the challenged law), Rowbotham J. reluctantly deferred to Wittman J.'s finding that the claimant group suffered historic prejudice and stereotyping, but she disagreed with the trial judge's conclusion that the minor injury cap perpetuated this stereotype. Justice Rowbotham held that the minor injury cap does not perpetuate the stereotype that soft tissue injury claimants are malingerers or fakers because the automobile insurance scheme as a whole, including the DTPR and the AAIBR, "recognizes that those who suffer soft-tissue injuries require early, affordable treatment." She found that the diagnosis and treatment offered by the DTPR and the AAIBR recognizes 
the reality of soft tissue injuries and that "[t]his is the antithesis of the perpetuation of the stereotypic soft-tissue victim who fakes or malingers his or her injury." ${ }^{47}$

For similar reasons, Rowbotham J. found that the trial judge erred in concluding that the legislation does not correspond to the needs and circumstances of the claimant group as per the second Law factor. She held that the needs of the claimants are medical diagnosis and treatment, compensation for out of pocket expenses, and a recognition of pain and suffering and loss of amenities of life. While acknowledging that the low limit on non-pecuniary damages set by the minor injury cap meets the latter need in minimal terms that are "unlikely to address each claimant's individual circumstance," 48 she concluded that most of the identified needs are met by the automobile insurance scheme as a whole. She found that, taken together, the MIR and the DTPR provide for personalized assessment and treatment of injury and the $A A I B R$ provides for increased and immediate payment of treatment costs. In short, Rowbotham J. concluded that "the insurance reforms as a whole correspond with the needs and circumstances of the claimants," ${ }^{49}$ though this correspondence is not perfect. Justice Rowbotham relied on Gosselin ${ }^{50}$ for the principle that "perfect correspondence between the program and the actual needs and circumstances of the claimant group is not required to find that a challenged provision does not violate the Charter."51

Finally, with regard to the fourth Law factor (whether the nature of the interest affected is severe, localized, and constitutionally and societally significant), Rowbotham J. again disagreed with the finding of Wittmann J. While noting that non-pecuniary damages are an important aspect of tort law recovery, she pointed out that damage recovery can be, and often is, limited by policy considerations. Accordingly, she concluded that, "while the nature of the interest affected is important to a reasonable minor injury claimant in the economic sense and in the recognition of her pain and suffering.... it is not an interest which is fundamental either societally or constitutionally." 52 In reaching this conclusion, Rowbotham J. acknowledged that policy interests in limiting non-pecuniary damage recovery logically form part of the s. 1 analysis. She concluded, however, that according to Supreme Court s. 15(1) jurisprudence, "much of the analysis which might logically form part of the section 1 analysis has become an important part of the analysis of the four contextual factors in Law, particularly, the second and fourth contextual factors.",53

In summary, the Court of Appeal's rejection of Wittmann J.'s finding that the minor injury cap is discriminatory turns on the appellate Court's view that, in considering whether the cap perpetuates a negative stereotype and in considering three of the four Law factors, Wittmann J. failed to consider the impact of the insurance reforms as a whole. As stated by Rowbotham J. at the conclusion of her s. 15(1) analysis:

Ibid.

Ibid. at para. 118.

Ibid. at para. 126.

Gosselin v. Quebec (Attorney General), 2002 SCC 84, [2002] 4 S.C.R. 429 [Gosselin].

Morrow, supra note 1 at para. 124

Ibid. at para.135.

Ibid. at para. 134. Justice Rowbotham specifically identified Law, Gosselin, Granovsky v. Canada (Minister of Employment and Immigration), 2000 SCC 28, [2000] 1 S.C.R. 703 [Granovsky], and Nova Scotia (Workers' Compensation Board) v. Martin, 2003 SCC 54, [2003] 2 S.C.R. 504 [Martin] as standing for this principle, which she noted is unchanged by Kapp and Ermineskin. 
The trial judge erred in failing to analyze the insurance reforms as a complete package. His focus on the MIR resulted in a flawed assessment of the Law contextual factors.... I conclude that his determination that individuals suffering minor soft tissue injuries are subject to stereotyping is entitled to deference. However, I find he erred in concluding that the insurance reforms as a whole perpetuate that stereotype. In my view, he failed to analyse the insurance reforms as a whole, including the DTPR, which rather than perpetuating the stereotype, recognizes that the injuries suffered by the MIR claimants are real and ought to be treated as such. Similarly, in analysing whether the legislation meets the needs and circumstances of the claimants, the trial judge failed to assess the medical benefits provided to minor injury claimants in exchange for their reduced damages for pain and suffering. Finally, he erred in concluding that damages for pain and suffering are of such fundamental societal significance that to interfere with them was indicative of discrimination. Accordingly, I conclude that in applying the four contextual factors from Law, a reasonable person in the position of the minor injury claimants would not conclude that the distinction drawn by the cap on nonpecuniary damages is discriminatory. ${ }^{54}$

\section{Three CONSTITUTiOnAL LAW ISSUES RAised BY THE COURT OF APPEAL'S RULING}

\section{A. WHAT ARE THE IMPLICATIONS OF KAPP ON THE ROLE OF THE LAW FACTORS IN A SECTION 15(1) ANALYSIS?}

The most obvious constitutional issue raised by the Court of Appeal's ruling in Morrow relates to the approach that Canadian courts should take to a s. 15(1) analysis in light of the Supreme Court of Canada's ruling in Kapp. Specifically, what role do the Law factors now play in a s. 15(1) analysis? When, how, and to what extent should the Law factors be utilized to evaluate legislative compliance with the Charter's equality guarantee? In Kapp, the Supreme Court expressly eliminated the concept of "human dignity" as a legal measurement of discrimination, but the Court does not clearly explain what role, if any, is now served by the Law factors in a s. 15(1) evaluation.

Kapp involved a Charter challenge to federal fishing regulations that authorized the granting of a communal fishing licence to aboriginal communities. The Supreme Court relied upon s. 15(2) of the Charter to uphold the challenged government action and therefore found it unnecessary to apply s. 15(1). ${ }^{55}$ Nonetheless, the Court discussed the appropriate interpretation and application of s. 15(1), focusing in particular on the legal tests previously articulated by the Supreme Court in Andrews ${ }^{56}$ and in Law. The Court's commentary on s. 15(1) breaks down to four crucial points:

- First, the Court reaffirmed its "commitment to substantive equality”57 in applying s. 15(1). This means that equality under the Charter requires more than formal equality, or treating like people alike.

$54 \quad$ Morrow, ibid. at para. 137.

55 The Charter, supra note 3, s. 15(2) provides that:

Subsection (1) does not preclude any law, program or activity that has as its object the amelioration of conditions of disadvantaged individuals or groups including those that are disadvantaged because of race, national or ethnic origin, colour, religion, sex, age or mental or physical disability. Andrews v. Law Society of British Columbia, [1989] 1 S.C.R. 143 [Andrews].

Kapp, supra note 41 at para. 14. 
- Second, the Court confirmed that the two-part test established in Andrews (the Andrews test) is the appropriate legal test for determining whether a challenged government action meets the requirement of substantive equality. The Andrews test is: "(1) Does the law create a distinction based on an enumerated or analogous ground? (2) Does the distinction create a disadvantage by perpetuating prejudice or stereotyping?"58

- Third, recognizing that the "human dignity" element of the Law test makes a poor legal standard, the Court stated that the focal issue of the second part of the Andrews test should be on whether the challenged government action perpetuates prejudice or stereotyping and not on whether the government action offends the claimant's human dignity as was suggested in Law. In the words of the Court:

In Law, this Court suggested that discrimination should be defined in terms of the impact of the law or program on the "human dignity" of members of the claimant group, having regard to four contextual factors: (1) pre-existing disadvantage, if any, of the claimant group; (2) degree of correspondence between the differential treatment and the claimant group's reality; (3) whether the law or program has an ameliorative purpose or effect; and (4) the nature of the interest affected.

But as critics have pointed out, human dignity is an abstract and subjective notion that, even with the guidance of the four contextual factors, cannot only become confusing and difficult to apply; it has also proven to be an additional burden on equality claimants

The analysis in a particular case, as Law itself recognizes, more usefully focusses on the factors that identify impact amounting to discrimination. The four factors cited in Law are based on and relate to the identification in Andrews of perpetuation of disadvantage and stereotyping as the primary indicators of discrimination.

Viewed in this way, Law does not impose a new and distinctive test for discrimination, but rather affirms the approach to substantive equality under s. 15 set out in Andrews and developed in numerous subsequent decisions. $^{59}$

- Fourth, the Court cautioned against a formalistic application of the Law factors, stating that

the factors cited in Law should not be read literally as if they were legislative dispositions, but as a way of focussing on the central concern of s. 15 identified in Andrews - combatting discrimination, defined in terms of perpetuating disadvantage and stereotyping. ${ }^{60}$ 
The third and fourth points above leave considerable ambiguity about the role of the Law factors. In the absence of the human dignity component, is it necessary for a court to employ the Law factors to conduct a proper s. 15(1) analysis? Further, if the Law factors are applied, how should they be applied to avoid being "read literally”?

In Morrow, the Court of Appeal held that the Kapp decision does not mean that it is an error of law for a court to apply the Law factors. The appeal Court did not, however, go so far as to say that the Law factors must be applied. Presumably, this is because the Supreme Court in Kapp only characterized the four factors as " $a$ way of focussing on ... combatting discrimination, defined in terms of perpetuating disadvantage and stereotyping." 61 Notably, the Supreme Court did not say that the Law factors are the way, the only way, or even the best way of deciding whether a challenged government action perpetuates prejudice or stereotyping.

Since Kapp ${ }^{62}$ the Supreme Court has decided three cases dealing specifically with the Charter's equality guarantee: Ermineskin, ${ }^{63}$ A.C., ${ }^{64}$ and Hutterian Brethren. ${ }^{65}$ Only Ermineskin was decided before the appellate Court's ruling in Morrow so it is the only postKapp Supreme Court case referenced by the Court of Appeal. In all three of these post-Kapp cases, however, the Supreme Court found that the challenged legislation did not violate the Charter's equality provision. ${ }^{66}$ Further, in each of these three cases, the Court came to this conclusion by applying the two-part Andrews test endorsed in Kapp, but without specifically considering or applying the Law factors.

In contrast, trial and appellate level courts across the country have generally continued to apply the Law factors in conducting a s. 15(1) Charter analysis, though they have varied

Ibid. [emphasis added].

Up to 29 June 2009.

Supra note 42.

A.C. v. Manitoba (Director of Child and Family Services), 2009 SCC 30, 390 N.R. 1 [A.C.].

Alberta v. Hutterian Brethren of Wilson Colony, 2009 SCC 37, 390 N.R. 202 [Hutterian Brethren].

In Ermineskin, the Supreme Court unanimously concluded that the money management provisions in the Indian Act, R.S.C. 1985, c. I-5, ss. 61-68, do not violate s. 15(1) of the Charter. The Court found that the first component of the Andrews test was satisfied, but that the challenge failed on the second component because the provisions did not impose a disadvantage that perpetuates prejudice or stereotyping of aboriginal bands. In A.C., six of seven Supreme Court Justices concluded that Manitoba's Child and Family Services Act, S.M. 1985-86, c. 8, C.C.S.M c. C80, ss. 25(8)-(9), which authorize a court to order medical treatment of a child under the age of 16 , do not violate the Charter's equality guarantee. In two concurring judgments, the majority of the Court again found that the first component of the Andrews test was satisfied, but that the legislation did not discriminate under the second part of the Andrews test. In Hutterian Brethren, a majority of four Supreme Court Justices held that Alberta's Operator Licensing and Vehicle Control Regulation, Alta. Reg. 320/2002, s. 14(1)(b), as am. by Alta. Reg. 137/2003, s. 3, did not violate the equality rights of members of the Wilson Colony of Hutterian Brethren by requiring all applicants for driver's licences to have their photographs taken, despite the fact that the religious beliefs of the colony members prohibited them from voluntarily having their pictures taken. After identifying the two-part equality test cited in Kapp, the majority of the Court in Hutterian Brethren completed its entire s. 15(1) analysis in only two sentences:

Assuming the respondents could show that the regulation creates a distinction on the enumerated ground of religion, it arises not from any demeaning stereotype but from a neutral and rationally defensible policy choice. There is no discrimination within the meaning of Andrews v. Law Society of British Columbia ... as explained in Kapp (Hutterian Brethren, ibid. at para. 108).

In fairness, the majority's s. 15(1) analysis was particularly cursory because the Court was of the view that the substance of the Charter challenge was dealt with under s. 2(a) (freedom of religion). Indeed, the three dissenting justices did not comment on the equality question at all and decided the case on the basis of freedom of religion only. Nevertheless, the majority's brief treatment of the s. 15(1) question shows no express consideration of the Law factors. 
somewhat in their approach. ${ }^{67}$ Despite this trend, however, to date ${ }^{68}$ few of these courts have made a clear statement as to whether the Law factors must be applied to a s. 15(1) analysis given the Supreme Court's ruling in Kapp. In Gill, the Federal Court of Appeal held that it was "necessary" to consider the Law factors when conducting a s. 15(1) analysis. ${ }^{69}$ Similarly, in Hartling, Goodfellow J. of the Nova Scotia Supreme Court interpreted Kapp as compelling the application of the Law Factors because they are "the primary (but not exclusive) indicators of discrimination."70 Other courts, however, have been less definitive about the need to apply the Law factors. For example, in McIvor, the British Columbia Court of Appeal did not apply each of the Law factors. Nonetheless, the Court stated that the Supreme Court's comments in Kapp should not be taken as rendering the Law factors unimportant because "[t]he factors do serve as indicators of discriminatory treatment, and can be very useful in determining whether differential treatment is discriminatory."71 In Cunningham, the Alberta Court of Appeal interpreted Kapp as saying that the Law factors are "still relevant" to a discrimination analysis. ${ }^{72}$

Overall, then, the post-Kapp jurisprudence (including Morrow, but more particularly including the Supreme Court's decisions in Ermineskine, A.C., and Hutterian Brethren), suggests that the application of the Law factors is a possible, but not a necessary, way of determining whether government action is discriminatory under s. 15(1) of the Charter. If this interpretation of the case law is correct, a further critical question remains: how should a court decide when the application of these factors is necessary or beneficial to the equality analysis? This question has not yet been addressed by any of the post-Kapp cases.

Kapp and subsequent case law to date also provide little guidance as to how the Law factors should be applied once the decision to apply them has been made. What does it mean to apply the Law factors, not "literally," but "as a way of focussing” on the perpetuation of disadvantage and stereotyping as suggested in Kapp? Presumably, the Supreme Court would not have admonished against a literal application of the Law factors if it had been satisfied with the manner in which the courts had been applying these factors. In Kapp, the Supreme Court appeared to be concerned about courts using the Law factors in a formalistic manner,

For example, the post-Kapp s. 15(1) cases in which the court's analysis advanced to the second stage of the Andrews test and in which all of the Law factors were expressly applied include: Cunningham v. Alberta (Minister of Aboriginal Affairs and Northern Development), 2009 ABCA 239, 457 A.R. 297 at para. 35 [Cunningham] (in this case the Alberta Court of Appeal took a more nuanced approach to its application of the Law factors. The Court of Appeal noted that, according to Kapp, "[d]iscrimination can be found through two avenues: decisions or laws that perpetuate the prejudice or disadvantage of a claimant, and decisions or laws that are based on inaccurate stereotypes.” The Court then dealt with each avenue separately, applying different contextual factors to each avenue); Plesner v. British Columbia (Hydro and Power Authority), 2009 BCCA 188, 269 B.C.A.C. 240; Vilven v. Air Canada, 2009 FC 367, 74 C.C.E.L. (3d) 1; Gill v. Canada, 2009 FCA 56, 387 N.R. 166 at para. 8 [Gill] (the appeal Court in this case did not go through each of the Law factors individually, but provided a blanket endorsement of the trial judge's findings on all of the Law factors); Hartling v. Nova Scotia (Attorney General) 2009 NSSC 2, [2009] I.L.R. I-4795 [Hartling]; Withler v. Canada (Attorney General), 2008 BCCA 539, 87 B.C.L.R. (4th) 197. Examples of the post-Kapp s. 15(1) cases in which the court's analysis advanced to the second stage of the Andrews test and in which each of the Law factors was not expressly applied (though reference may generally have been made to the Law factors) include: McIvor v. Canada (Registrar, Indian and Northern Affairs), 2009 BCCA 153, 91 B.C.L.R. (4th) 1 [McIvor]; Re Marshall Estate, 2009 NSCA 25, 275 N.S.R. (2d) 383.

Up to the end of June 2009.

Gill, supra note 67 at para. 7 .

Hartling, supra note 67 at para. 19.

McIvor, supra note 67 at para. 108.

Cunningham, supra note 67 at para. 35. 
but the Court gave no guidance as to when or how reliance on these factors will produce a formalistic result. The Kapp ruling does not clearly identify the problem with previous applications of the Law factors, apart from the fact that the Law factors were previously associated with the human dignity component of the Law test.

In McIvor, the British Columbia Court of Appeal interpreted the Supreme Court's comments in Kapp as a warning against an "overly technical” application of the Law factors and stated that

[i]n analyzing s. 15 claims, Canadian courts enthusiastically embraced the four contextual factors set out in Law. In adopting a sort of "checklist” approach to the concept of discrimination, however, they ran the risk of transforming the s. 15 analysis into an inquiry more concerned with formal than with substantive equality. In R. v. Kapp ... the Supreme Court of Canada revisited the issue of discrimination, and cautioned courts about an overly technical application of the Law criteria....

The factors in Law ... must not be applied in a mechanical fashion. ${ }^{73}$

Along similar lines, in Harris v. Canada (Minister of Human Resources and Skills Development) ${ }^{74}$ Linden J., in dissent, linked the Supreme Court's admonition against a literal application of the Law factors to the Court's commitment to s. 15(1) as a protector of substantive equality: "In my view, in Kapp the Supreme Court calls for a recommitment to the ideal of substantive equality.... This court must ensure that the Law factors are not used as a mere cloak for formalism." ${ }^{\text {,5 }}$ These descriptions of the Kapp ruling, however, do not answer the essential question: what is an "overly technical," "mechanical," or "checklist" application of the Law factors? Does this mean that the Law factors can be applied on a piecemeal basis; employing some but not all factors in a given case or employing the factors in some cases but not others? How much weight should be given to each factor in order to avoid an overly technical application of the factors? The difficulty in finding answers to these questions from existing Supreme Court case law is made clear by Goodfellow J. in Hartling, where, after concluding that he was required to apply the Law factors to a determination of whether Nova Scotia's automobile injury cap violated s. 15(1) of the Charter, he stated that:

As a trial judge I have some difficulty following the directions given by the Supreme Court of Canada. I am compelled to, as I am now doing, consider the four factors which are neither exhaustive nor is any one factor paramount or is a majority of them required to find discrimination has been proven on a balance of probabilities. $^{76}$

In Morrow, the Court of Appeal acknowledged the Supreme Court's call to focus the contextual inquiry on the question of substantive discrimination and to avoid a formalistic application of the Law factors. Nevertheless, the Court of Appeal then proceeded with a step by step analysis of each of the Law factors, which, except for the absence of an express human dignity consideration, appears to be indistinguishable from the approach that any 
court would have taken prior to Kapp. Is this approach too mechanical or technical? And perhaps more importantly, how do we know?

\section{B. What is the Proper Approach to a Section 15(1) Analysis WHERE THE CHALlenged PROVISION IS ClOSELy LiNKED TO A LARGER LEGISLATIVE SCHEME?}

As discussed in Part II.D of this comment, in Morrow, the Court of Appeal overturned Wittmann J.'s finding on s. 15(1) primarily because the appeal Court found that the trial judge had failed to evaluate the automobile insurance scheme as a whole. As stated by Rowbotham J. in the introduction to her reasons for judgment:

\footnotetext{
The Supreme Court of Canada jurisprudence mandates that in analyzing impugned legislation under section 15 or the Charter, the court must assess the entire legislative scheme. I conclude that the trial judge failed to do so, and that when the entire scheme of the legislation is assessed, it does not infringe section 15 of the Charter. $^{77}$
}

By his own description, the process of analysis followed by Wittmann J., and the process which he found to be required by existing s. 15(1) jurisprudence, was to constitutionally assess only the challenged MIR, but to do so having "regard to the Other Regulations and the benefits they provide as part of the contextual analysis prescribed in Law."78 The Court of Appeal found this approach to be in error, holding that, according to existing Supreme Court of Canada case law, "[i]t is clear that when the court considers a section 15 challenge to a section or to one part of a legislative scheme, it must consider the whole scheme."

It is important to note that the appeal Court did not criticize the trial judge for failing to consider the legislative context of the MIR. It is clear from the trial judgment that Wittmann J. did give regard to the automobile regulatory scheme. The Court of Appeal's objection is that the trial judge did not focus sufficiently on this context. In particular, the appellate Court objected to Wittmann J.'s fundamental approach to the question of discrimination under the last part of the Andrews and Law tests:

\footnotetext{
The trial judge erred when he "constitutionally assessed only the MIR" and stated that "the distinction in the MIR was the focus of [his] analysis.” The correct approach was to assess the entire package of insurance reforms.
}

Although the trial judge reviewed the entire scheme of the insurance reforms and was aware of their interrelationship, his method of analysis was to assess only the MIR, and then look to see if the other regulations would "offset" the MIR... [I]t resulted in a failure to analyze the scheme as a whole. ${ }^{80}$

In summary, Wittmann J. conducted the discrimination analysis on the basis of the following question: does the minor injury cap, looked at in the context of the automobile regulatory scheme, perpetuate prejudice or a negative stereotype against the claimant group? According 
to the Court of Appeal, the trial judge should have asked: does the legislative automobile regulatory scheme, as a whole, including the minor injury cap, perpetuate prejudice or a negative stereotype against the claimant group? ${ }^{81}$

According to the Court of Appeal, this is "not merely a semantic difference; nor is it a mere reweighing of the evidence." ${ }^{\text {I I }}$ am not convinced that the Court of Appeal is correct on this point. Looking closely at each court's application of the Law test and the Law factors, it seems that the trial and appellate courts come to divergent conclusions on the discrimination question because they have different views about the combined impact of the $M I R$, the DTPR, and the AAIBR on the perpetuation of prejudice or stereotyping against minor injury claimants. Both courts consider the overall context of the automobile insurance regulatory scheme. Justice Wittmann's approach emphasizes that his disposition of the case required only a finding as to the constitutionality of the $M I R$ rather than the automobile insurance scheme in its entirety. ${ }^{83}$ Justice Wittmann did not, however, view the MIR in isolation when applying the Law factors.

Nonetheless, the Court of Appeal's comments raise a question as to what the correct approach is to a s. 15(1) analysis where the challenged legislative provision is part of a larger legislative scheme and cannot be evaluated without regard to the whole scheme. In such circumstances, when applying the second part of the Andrews test, is a court compelled to evaluate the constitutionality of the legislative scheme as a whole? The Court of Appeal relied upon the Supreme Court of Canada's rulings in Gosselin and Martin to conclude that "[i]t is clear that when the court considers a section 15 challenge to a section or to one part of a legislative scheme, it must consider the whole scheme." ${ }^{84}$ Looking closely at these Supreme Court cases, however, it is not at all clear that the stated principle can be derived from them.

The appellate Court draws this principle from Gosselin on the basis that the Supreme Court repeatedly referred to the social assistance "scheme" in its s. 15(1) evaluation, even though the constitutional challenge in that case was directed only at s. 29(a) of the Regulation respecting social aid. ${ }^{85}$ The principle is drawn from Martin on the basis that,

This question is my own paraphrase of the Court of Appeal's reasoning.

Morrow, supra note 1 at para. 65.

This is an important distinction because a finding that the entire scheme is unconstitutional would deny all automobile accident injury victims the increased s. B coverage available under the AAIBR. Morrow, supra note 1 at para. 59.

R.R.Q. 1981, c. A-16, r. 1, as discussed in ibid. at para. 57 [emphasis in original], where the Court of Appeal stated, with reference to Gosselin [emphasis in original]:

The issue of the Charter violation was framed with reference to section 29(a) alone, and not to the whole of the Regulation.... Notwithstanding that the Charter challenge was directed only at a subsection, the court assessed and weighed the whole of the legislative scheme. This is made plain by the following references:

(a) the heading immediately preceding para. 16: "Does the Social Assistance Scheme [not section 29(a)] violate section 15(1) of the Canadian Charter?”;

(b) para. 20 says "we must approach the question of whether the scheme was discriminatory, in light of the purpose of the section 15 equality guarantee";

(c) para. 26 looks at the purpose of the distinction "in the context of the overall legislative scheme”; and

(d) para. 33 refers to the "programs" under the scheme.

Moreover, at para. 53 the court said: "The point is simply this: Ms. Gosselin has not established, on the records before us, that the scheme did not correspond to the needs and situation of welfare recipients under 30 in the short or long term." In short, the court in Gosselin evaluated and weighed the scheme, and not merely the challenged provision, in determining the constitutional validity of the impugned provision. 
when confronted with a challenge to the benefits provided to chronic pain sufferers by Nova Scotia's Workers' Compensation $A c t^{86}$ and underlying regulations, the Supreme Court "assessed the chronic pain regime under the Act" and "assessed the scheme as a whole." 7 The Court of Appeal relies on these specific quotations as authority for the proposition that a proper s. 15(1) analysis requires an evaluation of the whole legislative scheme that surrounds the challenged legislative provision. In fact, however, the Supreme Court did not, in either of these cases, expressly address the question of whether the constitutionality of the entire legislative scheme must be considered where a s. 15(1) challenge is brought to a single legislative provision. Moreover, in Martin, the constitutional challenge involved more than a single legislative provision. ${ }^{88}$ As a result, the Court necessarily had regard to other elements of the impugned legislation. Further, even if the Court of Appeal is correct in deriving this principle from Gosselin and Martin, these Supreme Court decisions may be distinguished from other s. 15(1) challenges, such as the challenge to the minor injury cap in Morrow, because they involved challenges to government benefit programs. Thus, the Court of Appeal's comments arguably do more to raise, rather than answer, the question of what approach courts should take when conducting a s. 15(1) analysis of a legislative provision that is closely tied to a larger compensatory regime.

\section{What IS THE Dividing Line BetWEen A SECTION 15(1) ANALYSIS AND A SECTION 1 ANALYSIS?}

Prior to Kapp, a problem with the "human dignity" element of the Law test was that its emphasis on context blurred the line between s. 15(1), which asks whether legislation treats the claimant group unequally, and s. 1 of the Charter, which asks whether the unequal treatment can be justified. ${ }^{89}$ Although Kapp dispensed with the human dignity concept as a legal test, the impact of Kapp on distinguishing between the facts relevant to a s. 15(1) analysis and those relevant to a s. 1 analysis is unclear. In McIvor, the British Columbia Court of Appeal offered the following interpretation of Kapp:

\footnotetext{
In Andrews, the members of the Supreme Court of Canada emphasized the importance of s. 1 in analyzing alleged Charter violations arising under s. 15. While there was, particularly after the Law decision, a tendency to treat all justifications as issues to be considered in determining whether differential treatment is "discriminatory", Kapp, in my view, serves as a reminder that the discrimination analysis is more narrow, and that policy justifications for unequal treatment under the law will normally be matters that must be treated outside of s. 15 itself. $^{90}$
}

In Morrow, however, the Alberta Court of Appeal had a different interpretation of Kapp on this point. As noted in Part II.D., Rowbotham J. took the position that Kapp does not alter the policy considerations that are relevant to a s. 15(1) analysis:

S.N.S. $1994-95$, c. 10.

Morrow, supra note 1 at para. 58 [emphasis in original].

The challenge was to Nova Scotia's Workers Compensation Act, supra note 86, s. 10B, and to the Functional Restoration (Multi-Faceted Pain Services) Program Regulations, N.S. Reg. 57/96.

Charter, supra note 3, s. 1. The text of s. 1 is set out in supra note 38.

McIvor, supra note 67 at para. 116. 
The respondents submit that the proper stage at which to look at whether non-pecuniary damages should yield to the policy interests is at the section 1 analysis. This is logical. However, I am compelled to observe that much of the analysis which might logically form part of the section 1 analysis has become an important part of the analysis of the four contextual factors in Law, particularly, the second and fourth contextual factors. This is clear from the Supreme Court jurisprudence including Law, Gosselin, Granovsky, and Martin, and in my view, has not changed as a result of the decisions in Kapp and Ermineskin. ${ }^{91}$

In short, the post-Kapp case law does not provide a clear picture as to the impact of Kapp on identifying the legislative policy considerations that are relevant to the s. 15(1) inquiry and those that are relevant to the s. 1 question.

To the extent that the overlap between the s. 15(1) and the s. 1 analysis has survived Kapp, this overlap is not merely of theoretical concern. It poses practical problems for the s. 15(1) inquiry because it is unclear whether and how the same contextual elements are to be weighed at the s. 15(1) stage and at the s. 1 stage of the constitutional analysis. This is an important question, not only because the courts have to grapple with the impact of contextual factors at both stages, but because, as the analysis shifts from s. 15(1) to s. 1, the burden of proof shifts from the claimant to the government. As stated by Peter Hogg, (who, incidentally, takes the view that Kapp does not clarify the overlap in the s. 15(1) and s. 1 analysis):

The inquiry into the reasonableness of a distinction that is based on a listed or analogous ground is not wholly remitted to s.1 (as Andrews so wisely insisted), but continues to be divided in a confusing way between the s.15 inquiry into discrimination and the s.1 inquiry into justification. And, because the inquiry into discrimination is part of s.15, it is the equality claimant who bears the burden of establishing that the use of a listed or analogous ground is a perpetuation of disadvantage or stereotyping. ${ }^{92}$

Morrow, supra note 1 at para. 134. The Supreme Court's rulings in A.C. and in Hutterian Brethren could now also be added to Rowbotham J.'s list of cases that suggest that some s. 1 considerations, and particularly the issue of legislative intention, may be brought into the s. 15(1) analysis. In her concurring judgment in A.C., supra note 64 at para. 152, McLachlin C.J.C. found that the legislation in question was not discriminatory in part because "it aims at protecting the interests of minors as a vulnerable group." Similarly, in Hutterian Brethren, supra note 65 at para. 108, McLachlin C.J.C. held that the challenged legislative distinction was not discriminatory because "it arises ... from a neutral and rationally defensible policy choice.” These comments arguably go some way toward suggesting that a legislative distinction must be intentionally discriminatory in order to violate s. 15(1). That is clearly not the law as stated in Andrews, supra note 56 at 173-75. Further, McLachlin C.J.C.'s focus on legislative intention in these cases seems to go back to a blending of the s. 15(1) and s. 1 analysis that was expressly rejected by McIntyre J. in Andrews, at 179, 181-82, when he overturned McLachlin, J.A. (as she then was), with regard to her interpretation of s. 15(1):

The second approach put forward by McLachlin J.A. in the Court of Appeal involved a consideration of the reasonableness and fairness of the impugned legislation under s. 15(1). She stated, as has been noted above, at p. 610:

The ultimate question is whether a fair-minded person, weighing the purposes of legislation against its effects on the individuals adversely affected, and giving due weight to the right of the Legislature to pass laws for the good of all, would conclude that the legislative means adopted are unreasonable or unfair.

She assigned a very minor role to s. 1 which would, it appears, be limited to allowing in times of emergency, war, or other crises the passage of discriminatory legislation which would normally be impermissible....

I would reject ... the approach adopted by McLachlin J.A. She seeks to define discrimination under s. 15(1) as an unjustifiable or unreasonable distinction. In so doing she avoids the mere distinction test but also makes a radical departure from the analytical approach to the Charter which has been approved by this Court. In the result, the determination would be made under s. 15(1) and virtually no role would be left for s. 1.

92 Peter W.Hogg, Constitutional Law of Canada, 5th ed. Supplemented, looseleaf (Scarborough: Thomson Carswell, 2007) vol. 2 at para. 55.9(d). 
The difficulty, in practice, of distinguishing between the facts relevant to the equality analysis and those relevant to the justification analysis, and the weight to be given to the facts under each inquiry, is illustrated in the Court of Appeal's reasoning in Morrow.

The Court of Appeal disagreed with the trial judge's assessment of the minor injury cap with regard to three of the four Law factors: (1) the perpetuation of a stereotype against minor injury claimants; (2) the correspondence between the alleged ground of discrimination and the needs, capacities, and circumstances of minor injury claimants; and (3) the nature of the interest affected. Leaving aside the question of whether the Court was correct in its conclusions in applying these elements, the Court's discussion of each of these factors clearly demonstrates the analytical problems created by the overlap that currently exists between the s. 15(1) and the s. 1 analyses. In other words, the parameters of a s. 15(1) analysis remain fuzzy, even after Kapp.

With regard to the first Law factor, the Court of Appeal held that, taken together, the relevant automobile accident injury regulations do not perpetuate a stereotype but "demonstrate that the legislature was of the view that sprains, strains and [whiplash associated disorders] are real injuries." ${ }^{\text {"93 }}$ This finding raises the question of whether, and to what extent, the legislature's perception of the claimant group is relevant to the question of whether the legislation perpetuates a stereotype. Andrews clearly states that s. 15(1) can be violated by a law that unintentionally marginalizes the claimant group..$^{94}$ Indeed, that is arguably one of the principles to be drawn from the Court's commitment to substantive equality. To the extent that the legislature's perception of the claimant group is constitutionally relevant, isn't that perception more appropriately addressed under s. 1 where the government bears the burden of proving its intentions and its perspective on the challenged legislation?

With regard to the correspondence factor, the Court of Appeal made two major findings. First, relying on Martin as establishing that "[t]he overall purpose of the legislative scheme must be considered in the context of this factor," ${ }^{, 95}$ the Court concluded that Alberta's automobile accident injury scheme serves a number of legitimate legislative purposes. Second, the Court held that, while the minor injury cap does not fully meet the need of minor injury claimants to recover damages for pain and suffering, the automobile accident injury scheme overall corresponds to the needs of claimants by providing treatment protocols, medical cost coverage, and some recovery for non-pecuniary damages. Generally, these two findings respectively reflect the two inquiries mandated under a s. 1 analysis: (1) whether the legislation serves a pressing and substantial objective; and (2) whether the legislation uses 
proportional means to achieve the objective. ${ }^{96}$ Again, exactly how these considerations differ at the s. 15(1) stage and at the s. 1 stage is not clear.

Finally, with regard to the nature of the interest affected, the Court of Appeal relied on Law as establishing that this factor evaluates the "discriminatory calibre of differential treatment" by "evaluating not only the economic but also the constitutional and societal significance attributed to the interest or interests adversely affected by the legislation in question." ${ }^{97}$ The Court concluded that the fact that damage caps have been imposed in Canada as a matter of legislative and judicial policy demonstrates that "the nature of the interest affected here is not of 'fundamental' societal or constitutional importance." ${ }^{\text {"98 }}$ Once again, this analysis really amounts to a balancing of the importance of the legislative purpose and intention against the disadvantage that the challenged law imposes on the claimant group. What role, then, is left for s. 1 ? $^{99}$

The Court of Appeal's analysis of this factor also illustrates the danger of evaluating the importance or significance of the affected interest at the s. 15(1) stage of analysis. By deciding whether the interest affected is of fundamental importance without having to expressly balance this interest against the legislative purpose, as would be the case in a s. 1 analysis, legislative and judicial policy can be inadvertently elevated to constitutional status. The Court of Appeal held that the interest at issue under the MIR, that is, the ability of a minor injury claimant to recover compensation for non-pecuniary loss, is not constitutionally significant because it is often limited by legislation or judicially imposed caps. This reasoning is tautological. Charter analysis requires legislative policy to be evaluated against the Constitution and the societal values reflected therein. The fact that a particular legislative policy is enacted across the country or in various pieces of legislation should not be used as a standard for determining what is constitutional, particularly prior to the s. 1 stage of analysis where the importance of the legislative objective is at issue.

96 The test for a s. 1 analysis, as established by R. v. Oakes, [1986] 1 S.C.R. 103 and defined by later cases, can be summarized as follows:

1. Does the challenged legislation have a sufficiently pressing and substantial objective to warrant overriding a Charter right? If yes,

2. Are the means employed to achieve the objective proportional to the breach of the Charter right:

(a) Are the means rationally connected to the objective?

(b) Do the means employ the right no more than is necessary to accomplish the objective?

(c) Does the salutory effect of the legislation weigh favourably against the deliterious effect on the Charter right?

Morrow, supra note 1 at para. 128, citing Law, supra note 27 at para. 74.

Morrow, ibid. at para. 133.

See supra note 91 for commentary on recent Supreme Court of Canada cases on this point. In McIvor, supra note 67 at para. 115 [emphasis in original], the British Columbia Court of Appeal interestingly suggested that the judicial inclination to include legislative intention at the s. 15(1) stage of analysis is attributable to the pejorative connotations associated with a finding of discrimination and the conceptual difficulty therefore associated with justifying a s. 15(1) breach at the s. 1 stage:

I appreciate that the word "discrimination" is pejorative. At least as the word is used in common parlance, it is difficult to conceive of discrimination being justifiable. For this reason, there is a temptation to examine all justifications for legislation before labelling it "discriminatory." It is tempting, in other words, to view s.15 as having its own internal limitations such that resort to s.1 of the Charter to evaluate justifications is unnecessary. There are, of course, Charter provisions that do have internal limitations, such that s. 1 justifications for infringements are no more than theoretical possibilities - it is difficult, for example, to conceive of a s.1 justification for an unreasonable search and seizure which violates s. 8 of the Charter. Section 15, however, is not such a provision. 


\section{RETHINKING THE OUTCOME IN MORROW V. ZHANG}

I have argued elsewhere that Alberta's minor injury cap violates s. 15(1) under the Law test. ${ }^{100}$ I do not propose to re-argue that point here. I contend, however, that the Supreme Court's revival of the Andrews test in Kapp provides scope for a simpler s. 15(1) assessment of the MIR that avoids the constitutional conundrums raised by the Court of Appeal's reasoning and discussed in Part III of this comment. The trial court and the Court of Appeal agreed that the minor injury cap imposes a disadvantage on minor injury claimants on the basis of a prohibited ground. Both courts also accepted the proposition that minor injury claimants have historically been negatively stereotyped as malingerers or fraudsters who have not suffered genuine physical injury. Thus, according to Kapp's restatement of the Andrews test, the only remaining, albeit crucial, question is whether the minor injury cap perpetuates this negative stereotyping of minor injury claimants. Following the example of the Supreme Court's application of the Andrews test in Ermineskine, A.C., and Hutterian Brethren, this question can be answered without specifically applying the Law factors. I would further advocate a return to the Andrews test in conducting the s. 15(1) analysis without regard to legislative intention, leaving that issue for a s. 1 analysis.

The minor injury cap is part of an automobile accident insurance regulatory scheme that simultaneously provides benefits and imposes restrictions on minor injury claimants. The relevant features of that scheme are that:

- All insured automobile accident injury victims, including minor injury claimants, are entitled to a maximum of $\$ 50,000$ in s. B automobile insurance benefits for medical treatment. Since all automobile accident injury victims receive this benefit, this component of the legislative scheme is neutral with regard to the question of discrimination against minor injury claimants.

- Unlike other motor vehicle accident injury victims, for the first 90 days post-accident, persons suffering from certain soft tissue injuries are required to follow a particular treatment protocol. Under this protocol, payment for the first ten to 21 treatment sessions are payable by the claimant's s. B insurer without the need for prior approval. The treatment protocol provides for an individualized assessment and treatment of the claimant's condition, but the medical practitioners qualified to provide treatment must subscribe to a treatment philosophy consistent with the regulatory scheme and the course of treatment is selected from a designated list of "best practices.” Thus, the treatment protocol is not neutral in its perspective toward accident injury victims with soft tissue injuries:

If there is an ideological underpinning to these regulations, it is that certain strains, sprains and whiplash complaints are minor, fleeting injuries that can be dispatched within no more than 12 weeks if treated competently. Implicit is the notion that inappropriate or misguided medical treatment has previously contributed to the onset of chronic whiplash states. 
[T] he protocol ... compels a certain mindset, for example, that the patient be told that symptoms from the injury are temporary and do not reflect tissue damage, that complaints of pain have no currently detectable underlying cause, that a soft collar is not advised and that the prescription of muscle relaxants and narcotics is not authorized. In these and other ways, health care practitioners are being told by regulation how to treat patients. ${ }^{101}$

- After the 90-day treatment protocol, the soft tissue injury victim can be assessed by a health care practitioner or by a certified examiner to determine whether the injury is "minor" within the meaning of the regulatory scheme. If the soft tissue injury is classified as minor, then, unlike all other motor vehicle accident injury victims, the minor injury claimant is prohibited from recovering more than $\$ 4,000$ in non-pecuniary damages for the minor injury, even if a court assesses the non-pecuniary damages at a greater value.

- If the treatment protocol is not followed, the injured person is deemed to have suffered a minor injury.

So, accepting that people who suffer non-debilitating soft tissue injuries in motor vehicle accidents have been stereotyped as malingerers or fraud artists in the past, what message is sent by the minor injury cap, operating as it does as part of this scheme of benefits and obligations?

To start, the minor injury cap and the treatment regime undoubtedly send a message that motor vehicle accident victims who suffer mild to moderate soft tissue injuries are different than those who suffer other types of injuries and therefore merit specific regulatory treatment. Acknowledging, for the sake of argument, that the treatment protocols recognize that minor injury claimants need treatment and even accepting that the treatment protocols provide appropriate care, the treatment protocols are paternalistic. The protocols implicitly suggest that soft tissue accident victims would not seek or receive the best or most appropriate care unless it is mandated by regulation. Notably, accident victims with other types of injuries are not subject to a regulated treatment protocol.

But most important to the constitutional challenge, the minor injury cap states that, even where a minor injury claimant has followed the treatment protocol established by regulation, he or she is not entitled to receive the full amount of non-pecuniary damages assessed by a court even though other claimants are so entitled. The regulatory scheme singles out minor injury claimants for limited recovery of general damages solely because of the nature of the physical injury suffered. Accordingly, regardless of the legislative intent, the message is that there is something less worthy about minor injury claimants as a group. Combined with the treatment protocol's emphasis on a biopsychosocial approach, the message is that minor injury claimants do not suffer loss that should be compensable by conventional general damages. In other words, minor injury claimants cannot be trusted in their own descriptions of pain and suffering because they are either intentionally, or, because of some psychological flaw, unintentionally exaggerating their pain. In constitutional terms, the message is that, because of the nature of their physical disability, minor injury claimants are not worthy of the same access to the judicial system of tort recovery as people who incur other physical 
disabilities in an motor vehicle accident. If this is not the message to be taken from the minor injury cap, then why is the cap directed only at this select group of people, defined by the nature of their common injury? All other accident injury victims are entitled to prove the extent of their non-pecuniary loss in a court and to recover the non-pecuniary damages as awarded by that court. Minor injury claimants are not.

\section{CONCLUSION}

The equality right guaranteed by s. 15(1) of the Charter is widely acknowledged as a very difficult right to apply, largely because equality is necessarily a comparative concept. It is also challenging to apply because, fortunately, Canadian society has a well-developed sense of human rights so that most equality complaints are directed at subtle and nuanced violations of this Charter guarantee and not at flagrant equality breaches. We have moved far beyond the question of whether governments can use legislative power to segregate, by race, the use of schools, water fountains, and public transit. Nonetheless, our tradition of constitutional supremacy demands that the same principled analysis be brought to all equality challenges, even the most subtle of complaints.

The constitutional challenge to Alberta's minor injury cap is a good example of an equality complaint that requires detailed and careful analysis to appreciate the nuance of the alleged inequality. As illustrated by the detailed judgments of the Alberta Court of Queen's Bench and the Alberta Court of Appeal, the alleged violation is not necessarily immediately obvious, particularly given the complexities of the automobile accident insurance scheme as a whole. In this comment, I have attempted to offer some food for thought for future s. 15(1) jurisprudence by pointing out, through the example of Morrow, some serious issues that need to be resolved with regard to the s. 15(1) analysis. These questions need to be resolved so that Canadian courts are better equipped to deal any and all equality challenges under the Charter. In the end, on the basis of the most direct and simple evaluation of the minor injury cap possible under current Supreme Court of Canada case law and uncomplicated by the Law test or an itemized application of the Law factors, I remain of the view that the MIR breaches the Charter's equality guarantee. 